\title{
Effect of sward age on nitrate accumulation in ryegrass
}

\author{
A. Darwinkel
}

Research Station for Arable Farming, Edelhertweg 1, Lelystad, the Netherlands

Accepted: 1 September 1976

Key words: nitrate content, nitrate accumulation, nitrate conversion, sward age, Lolium perenne, Lolium multiflorum

\section{Summary}

Two indoor trials were done with Italian ryegrass (Lolium multiflorum) and perennial ryegrass (Lolium perenne) to obtain more information about the nitrateaccumulating process of a new-sown grass sward.

With an abundant $\mathrm{NO}_{3}$ supply for Italian ryegrass, $\mathrm{NO}_{3}$ accumulation in herbage clearly decreased during five successive cuts after sowing, because of an increasing $\mathrm{NO}_{3}$ conversion. In the same way the $\mathrm{NO}_{3}$ content in dry matter in herbage of perennial ryegrass was considerably higher in the first cut after sowing than in old plants from a 5-year-old pasture.

After sowing, a considerable part of the assimilate produced was used for stubble and root growth. With older swards these assimilates were increasingly retained in herbage, which is rich in organic $\mathrm{N}$ and to a lesser extend in stubble and roots, which are poor in organic $\mathrm{N}$. Because of this, $\mathrm{NO}_{3}$ conversion is restricted in a new-sown grass sward and reaches to a maximum in old sward of a permanent pasture, which almost exclusively produces herbage. Consequently nitrate is more apt to accumulate in new-sown grass than in old pasture.

\section{Introduction}

As an important nutrient element, nitrogen has received much attention during research on how to increase dry matter yields. Maximum yields are only achieved with a sufficient supply of nitrogen. In grasses, this occurs in the presence of about $0.14 \% \mathrm{NO}_{3}-\mathrm{N}$ in dry matter (van Burg, 1965), but large amounts of $\mathrm{NO}_{3}$ in the plant are unhealthy for cattle.

Large contents of $\mathrm{NO}_{3}$ occur in various crops, as in oats (Gilbert et al., 1946) and more recently in stubble turnips (te Velde, 1967). Many articles describe factors that influence the $\mathrm{NO}_{3}$ content of the plant. Light intensity, drought, $\mathrm{N}$ fertilizer and plant species are often mentioned (Deinum, 1966).

In herbage from permanent pasture, high contents of $\mathrm{NO}_{3}$ hardly occur, not even 
after a large nitrogen dressing (de Groot et al., 1972). However, high $\mathrm{NO}_{3}$ contents have been found in herbage from newly sown grasses (Dapper \& Keuning, 1972; Thomas \& Willemsen, 1971). These high contents were attributed to heavy dressing with fertilizer and farmyard manure, but with similar fertilization the $\mathrm{NO}_{3}$ content of newly sown swards was considerably higher than that of older swards. So the question arises whether the newly sown swards themselves are a factor in increasing $\mathrm{NO}_{3}$ content.

This paper summarizes the results of two indoor trials, in which Kjeldahl $\mathbf{N}$ and nitrate $\mathrm{N}$ were estimated in (i) five successive cuts of Italian ryegrass and (ii) newsown and old perennial ryegrass. So the possible specific behaviour on nitrate accumulation of newly sown swards can be studied.

\section{Materials and methods}

The pot trials were in the phytotron of the Department of Field Crops and Grassland Husbandry, Agricultural University at Wageningen.

Trial 1. Dry matter production and nitrate accumulation in successive cuts of Italian ryegrass (Lolium multiflorum)

$0.6 \mathrm{~g}$ seed of Italian ryegrass $\mathrm{cv}$. Tetila was sown on a layer of fine gravel and placed on pots, containing 5 litres of a nutrient solution. The pots were placed in a growth cabinet at $16 / 12^{\circ} \mathrm{C}$ (day/night). Daylength was $15 \mathrm{~h}$ and daily irradiance was about $800 \mathrm{~J} \mathrm{~cm}^{-2} \mathrm{~d}^{-1}(400-700 \mathrm{~nm})$.

During the trial, the grass was cut five times at intervals of 3 weeks. After each growth period, the herbage was harvested and the nutrient solution renewed. The two $\mathrm{N}$ treatments were 400 and $800 \mathrm{mg} \mathrm{N}$ per pot after each cut. Each treatment included 5 pots per cut.

Trial 2. Effect of plant age on dry matter production and nitrate accumulation in perennial ryegrass (Lolium perenne)

On 30 September 1970, 5-litre plastic pots were filled with sandy soil and were kept in a temperature-controlled greenhouse with 4 replicates at $20 / 15^{\circ} \mathrm{C}$ (day/night). Plants of a 5-year-old pasture of perennial ryegrass sown as a mixture of $\mathrm{cv}$. Barenza and cv. Pelo, $1: 1$, were planted in half the pots on 6 October. On 9 November the other pots were sown with $0.9 \mathrm{~g}$ of the same mixture of grass seed. At the beginning of the trial on 23 November the old plants were cut for a second time, when the sown grass showed a good initial development. Afterwards 400 or $1000 \mathrm{mg} \mathrm{N}$ per pot were added. On 21 December, after 4 weeks, the plants were harvested.

Daylength was $14 \mathrm{~h}$ and average irradiance, including that of HPLR lamps, was about $950 \mathrm{~J} \mathrm{~cm}^{-2} \mathrm{~d}^{-1}(400-700 \mathrm{~nm})$.

\section{Analysis}

To obtain more information on the nitrate-accumulating process, harvested plants were separated into herbage, stubble and roots, since these tissues widely differ in nitrate metabolism (Darwinkel, 1975). After drying at $80^{\circ} \mathrm{C}$ for at least $20 \mathrm{~h}$, the 
dried material was ground through a $1-\mathrm{mm}$ sieve and stored in air-tight plastic bags for analysis.

For total nitrogen (including nitrate), the Kjeldahl method as modified by Deys (1961) was used. The content of $\mathrm{NO}_{3}$ was estimated potentiometrically with a nitrate-specific electrode.

\section{Results}

\section{Dry matter production}

The production and distribution of dry matter was recorded by weighing herbage, stubble and roots. Table 1 presents the results of both trials and Fig. 1 schematizes data from the treatment with heavy $\mathrm{N}$ dressing.

In Trial 1, dry matter yield increased with each successive cut, and reached a maximum at the 4 th cut. However in Trial 2, dry matter production of the old plants was considerably lower than of young plants, because of a small initial rate of regrowth of the old plants after cutting on 23 November.

Table 1 shows the total dry matter of each cut in Trial 1 was less than in Trial 2 , mainly because of the shorter period of growth. In both trials dry matter increased with $\mathrm{N}$ supply.

Table 1 also shows that herbage production was much greater than production of stubble + roots in each growth period. In Trial 1 , yield of herbage increased at each successive cut, but of stubble + roots was almost constant: an increasing proportion of production from sown grass was retained in herbage. At the 1st cut, more than $40 \%$ of dry matter was used for growth of roots and stubble, but at the 5 th cut this was less than $20 \%$.

In Trial 2, the differences in distribution of dry matter were even greater. The young plants laid down a considerable proportion of dry matter in stubble and roots,

Table 1. Increase of dry matter ( $\mathrm{g}$ per pot) of grasses at 2 nitrate dressings. A. Trial 1 : newly sown plants of Italian ryegrass during 5 successive cuts. B. Trial 2: newly sown and old plants of perennial ryegrass.

\begin{tabular}{|c|c|c|c|c|c|c|}
\hline \multirow[t]{2}{*}{ A. Trial 1} & \multicolumn{2}{|c|}{ Total dry matter } & \multicolumn{2}{|l|}{ Herbage } & \multicolumn{2}{|c|}{ Stubble + roots } \\
\hline & $400 \mathrm{mg} \mathrm{N}$ & $800 \mathrm{mg} \mathrm{N}$ & $400 \mathrm{mg} \mathrm{N}$ & $800 \mathrm{mg} \mathrm{N}$ & $400 \mathrm{mg} \mathrm{N}$ & $800 \mathrm{mg} \mathrm{N}$ \\
\hline 1st cut & 11.00 & 10.77 & 6.14 & 6.43 & 4.86 & 4.31 \\
\hline 2nd cut & 11.79 & 13.42 & 6.85 & 10.10 & 3.14 & 3.32 \\
\hline 3rd cut & 12.66 & 14.98 & 9.82 & 12.62 & 2.84 & 2.36 \\
\hline 4th cut & 15.93 & 18.94 & 11.48 & 13.89 & 4.45 & 5.05 \\
\hline 5th cut & 16.25 & 18.73 & 12.81 & 15.96 & 3.44 & 2.77 \\
\hline \multirow[t]{2}{*}{ B. Trial 2} & \multicolumn{2}{|c|}{ Total dry matter } & \multicolumn{2}{|l|}{ Herbage } & \multicolumn{2}{|c|}{ Stubble + roots } \\
\hline & $400 \mathrm{mg} \mathrm{N}$ & $1000 \mathrm{mg} \mathrm{N}$ & $400 \mathrm{mg} \mathrm{N}$ & $1000 \mathrm{mg} \mathrm{N}$ & $400 \mathrm{mg} \mathrm{N}$ & $1000 \mathrm{mg} \mathrm{N}$ \\
\hline New-sown plants & 21.04 & 22.12 & 12.88 & 14.53 & 8.16 & 7.59 \\
\hline Old plants & 15.79 & 16.75 & 14.37 & 16.13 & 1.42 & 0.62 \\
\hline
\end{tabular}


EFFECT OF SWARD AGE ON NITRATE ACCUMULATION IN RYEGRASS

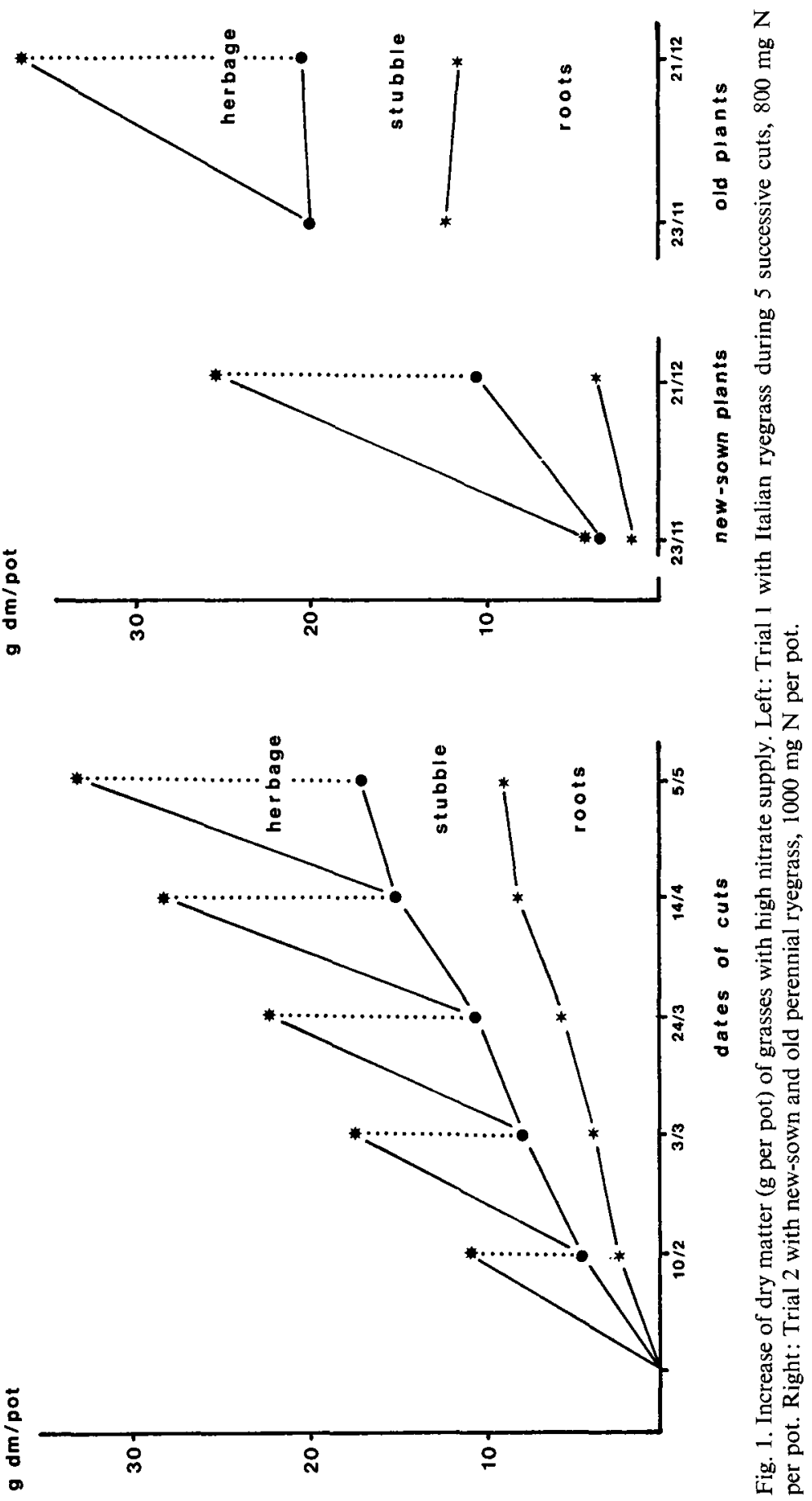

Neth. J. agric. Sci. 24 (1976) 
Table 2. Nitrate contents ( $\mathrm{g}$ nitrate $\mathrm{N} / 100 \mathrm{~g} \mathrm{dm}$ ) in herbage, stubble and roots of Italian ryegrass in 5 successive cuts (Trial 1) and of newly sown and old perennial ryegrass plants (Trial 2) at $2 \mathrm{~N}$ dressings.

\begin{tabular}{|c|c|c|c|c|c|c|}
\hline \multirow[t]{2}{*}{ Trial 1} & \multicolumn{2}{|l|}{ Herbage } & \multicolumn{2}{|l|}{ Stubble } & \multicolumn{2}{|l|}{ Roots } \\
\hline & $400 \mathrm{mg} \mathrm{N}$ & $800 \mathrm{mg} \mathrm{N}$ & $400 \mathrm{mg} \mathrm{N}$ & $800 \mathrm{mg} \mathrm{N}$ & $400 \mathrm{mg} \mathrm{N}$ & $800 \mathrm{mg} \mathrm{N}$ \\
\hline 1st cut & 0.88 & 1.66 & 0.71 & 1.33 & 0.38 & 1.43 \\
\hline 2nd cut & 0.61 & 1.27 & 0.70 & 1.31 & 0.39 & 1.07 \\
\hline 3 rd cut & 0.55 & 1.24 & 0.82 & 1.52 & 0.37 & 0.58 \\
\hline 4th cut & 0.31 & 0.93 & 0.44 & 1.41 & 0.11 & 0.38 \\
\hline 5 th cut & 0.22 & 0.84 & 0.29 & 0.96 & 0.07 & 0.22 \\
\hline \multirow[t]{2}{*}{ Trial 2} & \multicolumn{2}{|l|}{ Herbage } & \multicolumn{2}{|l|}{ Stubble } & \multicolumn{2}{|l|}{ Roots } \\
\hline & $400 \mathrm{mg} \mathrm{N}$ & $1000 \mathrm{mg} \mathrm{N}$ & $400 \mathrm{mg} \mathrm{N}$ & $1000 \mathrm{mg} \mathrm{N}$ & $400 \mathrm{mg} \mathrm{N}$ & $1000 \mathrm{mg} \mathrm{N}$ \\
\hline New-sown plants & 0.21 & 0.63 & 0.26 & 0.66 & 0.04 & 0.24 \\
\hline Old plants & 0.15 & 0.33 & 0.14 & 0.29 & 0.06 & 0.12 \\
\hline
\end{tabular}

whereas the old plants showed hardly any increase in stubble + roots. The increase in dry matter in old plants consisted mainly of herbage.

Nitrogen influenced distribution of dry matter in both trials. Herbage yield increased clearly with a higher nitrogen supply, but yield of stubble and roots was hardly affected.

\section{Nitrate contents}

Table 2 shows the $\mathrm{NO}_{3}$ content of herbage, stubble and roots in both trials. For a good comparison of $\mathrm{NO}_{3}$ contents, yield of dry matter must be known. In Trial 2, the $\mathrm{NO}_{3}$ content was lower than in Trial 1 , mainly because of the higher yield of dry matter. Clear differences in $\mathrm{NO}_{3}$ content existed between herbage, stubble and roots. The lowest contents were always found in roots. At the first cut of Trial 1, herbage had a higher $\mathrm{NO}_{3}$ content than stubble, but at successive cuts thereafter the reverse was found. In Trial 2, the differences in $\mathrm{NO}_{3}$ content between herbage and stubble were small. As expected, $\mathrm{NO}_{3}$ content in all plant parts increased with a higher $\mathbf{N}$ supply.

Plant age clearly influenced $\mathrm{NO}_{3}$ content. In Trial $1, \mathrm{NO}_{3}$ content continued to decrease at each of the 5 successive cuts. This decrease was clear in herbage and roots, but less pronounced in stubble. The effect of plant age was also present in Trial 2, in which old plants had considerably less $\mathrm{NO}_{3}$ than the young ones.

During the 5 consecutive growth periods of Trial $1, \mathrm{NO}_{3}$ content decreased by $80 \%$ with the low dressing and by $50 \%$ with the high dressing. Consequently the effect of $\mathrm{N}$ supply on $\mathrm{NO}_{3}$ content was highest at the 5 th harvest.

So the difference in $\mathrm{NO}_{3}$ content between old and newly sown swards, as found in practice, occurred also in these trials, indicating that $\mathrm{N}$ supply is of little bearing of these differences. 


\section{Discussion}

Accumulation of $\mathrm{NO}_{3}$ in plants is the difference between uptake and conversion of $\mathrm{NO}_{3}$. Uptake depends closely upon the supply of nitrogen, whereas conversion depends upon production and distribution of dry matter (Darwinkel, 1975). Knowledge about dry matter production and about uptake and conversion of $\mathrm{NO}_{3}$ is necessary to analyse the nitrate-accumulating process.

During initial growth of grasses after sowing, much assimilate is used for root and stubble development. In course of time, a dense sward and an extensive root system is produced. Gradually the weight of stubble and roots practically stabilizes. Then, stubble and roots will take little more assimilate than is necessary to compensate for ageing parts. Such an equilibrium is found in permanent pasture.

To achieve this equilibrium a gradual change takes place in the distribution of dry matter between herbage, stubble and roots. During ageing of the sward, an increasing proportion of the dry matter produced is retained in herbage. This change in dry matter distribution favours nitrate conversion as the content of organic $\mathbf{N}$ in herbage is considerably higher than in stubble and roots (Alberda, 1965; Darwinkel, 1975).

This equilibrium in distribution of dry matter was not yet reached in Trial 1 after 5 cuts (Table 1). During the first growth period after sowing, more than $40 \%$ of dry matter was retained in roots and stubble. During successive periods of the growth, this share decreased gradually to less than $20 \%$ at the 5th cut. Also in Trial 2, $40 \%$ of the dry matter produced was in stubble and roots of the young plants, whereas weight of stubble and roots hardly changed in old plants (Table 3).

Yield increases of dry matter and nitrogen are presented in Table 3.

In Trial 1, the increments of dry matter in whole plant and in herbage were higher in each successive cut (Table 1). In Trial 2 increment of dry matter of old plants lagged behind that of young plants, because of the slow initial regrowth.

With the same abundant $\mathrm{N}$ supply, nitrogen yield at the 5th cut of Trial 1 was greater than at the 1st cut, possibly because of the more extensive root system. The conversion of $\mathrm{NO}_{3}$ into organic $\mathrm{N}$ increased even more than $\mathrm{N}$ uptake, so that a

Table 3. Increment of dry matter $(\mathrm{g})$ and of nitrogen $(\mathrm{mg})$ per pot in Italian ryegrass at 1 st and 5 th cut (Trial 1 ) and in new-sown and old perennial ryegrass (Trial 2) with high $\mathrm{N}$ supply.

\begin{tabular}{lcccc} 
Dry matter production & Total N Nitrate N Organic N \\
\hline total & herbage & $\begin{array}{c}\text { stubble } \\
+ \text { roots }\end{array}$ & &
\end{tabular}

$\begin{array}{lrrrrrr}\text { Trial I } & & & & & & \\ \text { 1st cut } & 10.74 & 6.43 & 4.31 & 568 & 166 & 402 \\ \text { 5th cut } & 18.73 & 15.96 & 2.77 & 674 & 126 & 548 \\ & & & & & & \\ \text { Trial 2 } & & 14.53 & 7.59 & 703 & 137 & 566 \\ \text { New-sown plants } & 22.12 & 16.13 & 0.62 & 629 & 64 & 565 \\ \text { Old plants } & 16.75 & 13 & \end{array}$


Table 4. Amount (mg) and proportion of nitrate accumulated per pot in herbage and stubble + roots with high $\mathrm{N}$ supply in the two trials.

\begin{tabular}{|c|c|c|c|c|}
\hline & \multicolumn{2}{|c|}{ Amount of nitrate $(\mathrm{mg})$} & \multicolumn{2}{|c|}{ Proportion of nitrate $(\%)$} \\
\hline & herbage & stubble + roots & herbage & stubble + roots \\
\hline \multicolumn{5}{|l|}{ Trial 1} \\
\hline 1 st cut & 107 & 59 & 65 & 35 \\
\hline 5th cut & 134 & 103 & 57 & 43 \\
\hline \multicolumn{5}{|l|}{ Trial 2} \\
\hline New-sown plants & 95 & 55 & 63 & 37 \\
\hline Old plants & 51 & 43 & 54 & 46 \\
\hline
\end{tabular}

smaller amount of $\mathrm{NO}_{3}$ had been accumulated at the 5 th cut. Moreover, this lower $\mathrm{NO}_{3}$ accumulation was achieved at a higher yield of dry matter, so that the difference in $\mathrm{NO}_{3}$ content between the 1st and 5th cut was very high (Table 2). In Trial 2 both groups of plants converted equal amounts of $\mathrm{NO}_{3}$ into organic $\mathrm{N}$, so the greater uptake by young plants led to greater accumulation.

Leaves have a considerably higher content of organic $\mathrm{N}$ than the other plant parts, so growth of leaves determines $\mathrm{NO}_{3}$ conversion. In Trial 1 the greater yield of organic $\mathrm{N}$ at the 5th cut must mainly be attributed to a higher herbage yield. In Trial 2, the influence of herbage yield is even clearer. Although yield of dry matter in whole plants was less in old plants, yield of herbage was more than in young plants, and so both plants contained equal amounts of organic $\mathrm{N}$.

So distribution of dry matter influences the conversion and accumulation of $\mathrm{NO}_{3}$. For morphologically different varieties of stubble turnip and for Italian and Westerwolths ryegrass, differences in $\mathrm{NO}_{3}$ conversion depend upon differences in yield of leaves (Darwinkel, 1975). So differences in $\mathrm{NO}_{3}$ content between species and varieties can be explained by differences in distribution of dry matter. If a considerable proportion of the dry matter produced accumulates in plant parts poor in organic $\mathrm{N}$, such as roots and stems, $\mathrm{NO}_{3}$ conversion is restricted. On the contrary, a large accumulation of dry matter in leaves stands for a good conversion. Perhaps low $\mathrm{NO}_{3}$ contents in perennials and the high contents in annuals (Kretschmer, 1958) are connected with this difference in dry matter distribution.

Measurements of the activity of the enzyme nitrate reductase showed that $\mathrm{NO}_{3}$ reduction occurs mainly in leaves (Wallace \& Pate, 1967). In grasses, green stubble also contributes to some extend to $\mathrm{NO}_{3}$ reduction (Darwinkel, 1975). Probably the great amount of stubble favoured $\mathrm{NO}_{3}$ conversion during the later growth periods of Trial 1 and in the old plants of Trial 2.

High $\mathrm{NO}_{3}$ contents rarely occur in permanent pasture, even with high $\mathrm{N}$ dressings (de Groot et al., 1972), possibly because dry matter is mainly produced as herbage, in which much $\mathrm{NO}_{3}$ can be converted into organic compounds. Moreover, a considerable proportion of the $\mathrm{NO}_{3}$ taken up can be accumulated in the large storage capacity of stubble and roots. Newly sown swards and annual grasses have only a limited capacity in stubble and roots and consequently a major part of the $\mathrm{NO}_{3}$ is 


\section{EFFECT OF SWARD AGE ON NITRATE ACCUMULATION IN RYEGRASS}

translocated to herbage. Table 4 presents distribution of $\mathrm{NO}_{3}$ between herbage, stubble and roots. With ageing of the sward, an ever smaller proportion of the $\mathrm{NO}_{3}$ is found in herbage. The high $\mathrm{NO}_{3}$ content in stubble (Table 2) indicates that $\mathrm{NO}_{3}$ accumulates there. With ageing, the amount of stubble increases and even more $\mathrm{NO}_{3}$ can accumulate in it. Accordingly, less $\mathrm{NO}_{3}$ is transported to herbage, whereas herbage yield increases with plant age (Fig. 1). This results in a sharp decrease in the $\mathrm{NO}_{3}$ content.

\section{Acknowledgments}

The author is much indebted to Prof. Ir M. L. 't Hart and Dr Ir B. Deinum for valuable comments and to Mrs Evelyn Zantman for technical assistance.

\section{References}

Alberda, Th., 1965. The influence of temperature, light intensity and nitrate concentration on dry matter production and chemical composition of Lolium perenne L. Neth. J. agric. Sci. 13: 335-360.

Burg, P. F. J. van, 1965. De stikstofbemesting van grasland. 7. Het nitraatgehalte als indicator voor de stikstofvoeding. Stikstof 47/48: 461-469.

Dapper, J. G. \& J. A. Keuning, 1972. Hoge nitraatgehalten in het gras en in grasprodukten op het bedrijf Reynen te Gemert. Stikstof 71: 476-483.

Darwinkel, A., 1975. Aspects of assimilation and accumulation of nitrate in some cultivated plants. Agric. Res. Rep. 843. Pudoc, Wageningen, 64 pp.

Deinum, B., 1966. Climate, nitrogen and grass. Research into the influence of light intensity, temperature, water supply and nitrogen on the production and chemical composition of grass. Meded. LandbHogesch. Wageningen 66-11; 91 pp.

Deys, W. B., 1961. De bepaling van totaal stikstof in gewasmonsters, inclusief nitraat-stikstof. Jaarb. Inst. biol. scheik. Onderz. LandbGewassen: 89-91.

Gilbert, C. S., H. F. Eppson, W. B. Bradley \& O. A. Beath, 1946. Nitrate accumulation in cultivated plants and weeds. Bull. Univ. Wyo. agric. Exp. Stn 277; 39 pp.

Groot, Th. de, J. A. Keuning \& L. Padmos, 1972. Hoge stikstofgiften op grasland en de produktie en gezondheid van melkvee. Stikstof 72: 495-532.

Kretschmer, A. E., 1958. Nitrate accumulation in Everglades forages. Agron. J. 50: 314-316.

Thomas, H. \& W. Willemsen, 1971. Hoge nitraatgehalten in graslandprodukten. Stikstof 68: 313-319.

Velde, H. A. te, 1967. Nitraatgehalten van stoppelknollen in 1966 (I).Meded. Proefstn Akker-en Weideb. $139 ; 46$ pp.

Wallace, W. \& J. S. Pate, 1967. Nitrate assimilation in higher plants with special reference to the cocklebur (Xanthium pennsylvanicum Wallr.). Ann. Bot. 31: 213-228. 